SHS Web of Conferences 2, 00017 (2012)

DOI: $10.1051 /$ shsconf $/ 20120200017$

(C) Owned by the authors, published by EDP Sciences, 2012

\title{
Prevalence of tabacco product use in Latvia and control measures
}

\author{
A. Kokarevica
}

Rīga Stradiņš University, Latvia

\begin{abstract}
The use of tobacco products is a major problem having a serious effect on public health. Deaths from external causes are those that can be prevented by ensuring environmental safety and educating the society about the effect of lifestyle habits and behaviour on health of an individual. Not only research data reveal the prevalence of tobacco use but also the rate of tobacco sales. Tobacco industry marketing includes advertising, sales promotion and sponsorship strategies that are aimed at promotion of tobacco use. Demand for tobacco products is influenced also by changes in legislation relating to ban on tobacco advertising and sponsorship. Therefore it is necessary to introduce an agreed strategy for reducing tobacco use. The countries that have ratified the World Health Organisation (WHO) Framework Convention on Tobacco Control (the Convention) should develop and implement an effective tobacco control programme. In Latvia the number of daily smokers gradually decreases thanks to the extensive smoking restrictions though tobacco manufacturers use all the available media, radio and television, newspapers, magazines, advertisements and Internet, to advertise their products. Therefore in order to combat the prevalence of smoking first of all it is necessary to limit cigarette marketing and sales and to carry out monitoring and development of tobacco control measures on the state level. The sales of legal cigarettes have decreased in Latvia starting from 2009. However, the increase in tax rates and prices has contributed to the movement of illegal goods therefore it is necessary to take additional restrictive measures concerning the movement of illegal goods. Though amendments to legislation of Latvia relating to tobacco control comply with the requirements of the WHO Convention it is necessary to evaluate the efficiency of control measures and to improve them. Systematic and comprehensive education of the public is required to encourage the change of public attitude in favour of a healthy lifestyle.
\end{abstract}

Key words: prevalence of tobacco use, tobacco control

The WHO data show that 1.3 billion people all over the world smoke, and every year about 5.4 million people die from the use of tobacco products (http://www.who.int/features/factfiles/tobacco_epidemic/ en/index.html). Recent European Commission Health and Consumer Directorate (Directorate General Health and Consumer) Eurobarometer survey indicates that $36 \%$ of the population of Latvia smoke. The countries with the highest rate of smoking population in Europe are Greece, where $42 \%$ of people confirm that they smoke, Bulgaria, 39\% of smoking people, and Hungary with $38 \%$ of smoking population. The lowest rate of smoking population is in Sweden (16\%) and Finland (21\%). Latvia has the highest rate of smoking population in the Baltic countries. 32\% of people smoke in Estonia and 30\% of people in Lithuania (http://www.narcomania.lv/pub/index.php?id=211\&gid=53\&lid=513).

The World Health Organisation (WHO) Framework Convention on Tobacco Control (the Convention) came into force in Latvia on 11th May 2005. The main measures determined by the Convention on reduction of demand for tobacco are: safeguarding public health policy against commercial interests of tobacco industry, protection from exposure to tobacco smoke, introduction of regulations on tobacco packaging and labelling and ban on tobacco advertising, promotion and sponsorship (http://www.likumi.lv/doc.php?id=98236).

This is an Open Access article distributed under the terms of the Creative Commons Attribution License 2.0, which permits unrestricted use, distribution, and reproduction in any medium, provided the original work is properly cited. 


\section{SHS Web of Conferences}

State Tobacco Monitoring Programme for 2006-2010 was adopted by the Cabinet of Ministers order No 852 of 28th December 2005. The main targets of this programme were to ensure: sustainable reduction of demand for tobacco products, limitation of the sale of tobacco products, broad awareness of risks of tobacco use and continuous monitoring of tobacco prevalence and its consequences. In accordance with the programme the Ministry of Health had to supervise the programme implementation plan and to submit the aggregate information on the accomplished activities to the Cabinet of Ministers (http://phoebe.vm.gov.lv/misc_db/web.nsf/bf25ab0f47ba5dd785256499006b15a4/17cb8c1218bf81cdc 2257313001f391a/\$FILE/Tabakas_Uzr_programma.pdf). The previous Public Health Strategy expired on $31^{\text {st }}$ December 2010; therefore the development of new guidelines was initiated involving a wide range of specialists. The main target is to increase the lifespan of the people of Latvia and to determine the main areas for the state policy to ensure the quality of life of the population by taking all possible measures in prevention of diseases caused by external factors and human lifestyle (http://www. vm.gov.lv/index.php? top=121\&id=798).

The aim of the study: to find out the trends in prevalence of tobacco use in Latvia and to evaluate the efficiency of the control measures.

\section{Methods}

The author of the Paper assessed the data of FINBALT health monitoring - research on Health behaviour of the population of Latvia (age group of 15-64), research on health behaviour of school-age children in Latvia within the framework of the Health Behaviour in School-aged Children (HBSC) monitoring supported by the World Health Organisation and the international survey on youth smoking in Latvia (Global Youth Tobacco Survey) (GYTS) (2002 and 2007). The author of the Paper analysed the laws and regulations of the Republic of Latvia - law "On limited sale, advertising and use of tobacco", law "On Excise Tax", regulations of the Cabinet of Ministers No 868 "Regulations on adding coloured photographs or illustrations on a tobacco packaging unit" and the compliance of laws and regulations with the requirements of the Convention of the WHO, clarified the goals and objectives of the State Tobacco Monitoring Programme for 2006-2010, used statistical data of the State Revenue Service (SRS) and summarised and analysed the data.

\section{Results}

Health behaviour determination every second year starting from 2008, FINBALT health monitoring is carried out in Latvia in cooperation with Finland and the Baltic countries. The information obtained helps to determine habits influencing health and changes in trends and to identify health problems. The data in all the FINBALT health monitoring member states are obtained using the same common methodology of mail surveys in random samples of general population. In Latvia State Population Register selected 3000 respondents at the age of 15 to 64 who were stratified by age and residence in four administrative territorial groups: Riga, large cities (Daugavpils, Liepaja, Ventspils, Rezekne, Jurmala and Jelgava), other urban and rural areas. Survey section on smoking provides information on smoking habits of the inhabitants of Latvia, passive smoking at work and at home, attitude towards smoking, knowledge of dangers of smoking and intentions to stop smoking (http://vec.gov.lv/docs/new2009/Finbalt_2_dala.pdf). The monitoring helps to assess how the smoking control policy is implemented in the country. FINBALT survey data show that in 2006 in Latvia $46.6 \%$ of men and $18.2 \%$ of women smoked on daily basis but in $2008-45.5 \%$ of men and $15.6 \%$ of women. In 2008 the number of daily smokers decreased by $2 \%$ in both gender groups in comparison with 2006. $16 \%$ of men and $6.2 \%$ of women were exposed to smoke at their workplaces in 2006 and $14.4 \%$ of men and $3.9 \%$ of women in 2008. The survey data of 2008 prove that the situation had improved in comparison with 2006, though the requirements concerning the ban on smoking at workplaces were not fully complied with and there was inadequate surveillance of implementing smoking ban. 


\section{Int. Conf. SOCIETY. HEALTH. WELFARE; Congr. of Rehabilitation Doctors of Latvia}

In Latvia the first schoolchildren health behaviour survey (HBSC) was carried out in the school year 1990/1991. The further surveys were repeated every four years according to the international research protocol. The target group of this survey is schoolchildren at the age of 11,13 and 15 . The survey data show that the proportion of schoolchildren who had tried smoking increased from $45.4 \%$ in 1991 to $57.2 \%$ in 2006 . The number of girls who had tried smoking increased significantly from $5.3 \%$ in 1991 to $22.7 \%$ in 2006 .

49 schools of general education in Latvia took part in the international schoolchildren smoking survey GYTS in 2007 and 3362 questionnaires were completed. The target group of the survey was schoolchildren at the age of 13 to 15 . The survey data show that at present $35.2 \%$ of girls and $41.8 \%$ of boys smoke cigarettes. $18.5 \%$ of schoolchildren smoke cigarettes on daily basis $(22.0 \%$ of boys and $15.0 \%$ of girls). The survey shows that water pipe smoking becomes more and more popular among Latvian young people. $33.1 \%$ of respondents mention that they smoked water pipe during the previous month. $71.9 \%$ of smokers (70.2\% of boys and $73.3 \%$ of girls) and $38.2 \%$ of non-smoking schoolchildren state that they live at homes where somebody smokes in their presence. $43.8 \%$ of nonsmoking and $64.5 \%$ of smoking young people state that one or both of their parents smoke. $46.7 \%$ of the schoolchildren state that they purchase cigarettes in shops and kiosks. $42.5 \%$ of schoolchildren consider that it is easy to buy cigarettes in a store. $59.6 \%$ of the schoolchildren agreed that the price increase for tobacco products might reduce the opportunity of purchasing tobacco products because in spite of the fact that the law bans the sale of tobacco products to people under the age of 18, young people can buy cigarettes at the points of sale and also illegally imported cigarettes.

The aim of the law "On limited sale, advertising and use of tobacco products" that was adopted on 18 December 1996 and came into force on 21 January 1997 is to protect human health and human rights to clean and smoke-free environment and to define the procedure how the state controls manufacturing, import and sale of tobacco and tobacco products, advertising of tobacco products and smoking in public places respecting people's rights and interests. (http://www.likumi.lv/doc.php?id=41774). Though it is stated in Section 8 of this law that: "Advertising of tobacco is allowed only in special editions designed for merchants who deal with trade in tobacco products and in editions issued and printed in non-Member States of the European Union and are not intended for the European Union market", this legal regulation is often violated. For example, different cigarette brands in coloured pictures with stated prices and names of the shops where you can obtain these cigarettes are advertised on the Internet. Manufacturers of tobacco products willingly sponsor a variety of sports and cultural events thus providing indirect advertising of their products (Дальке, 2010; 175). It is stated in Section 9 of the above mentioned law that: "It is prohibited to use misleading, deceptive and fraudulent means or other methods that might create delusion about the properties of tobacco, health effects of tobacco and dangers of tobacco use or substances that are released when using tobacco products". This regulation is also violated. For example, electronic cigarettes are being advertised as cheaper and less harmful to health than ordinary cigarettes, however it is not mentioned that the liquid in the capsule (cartridge/cassette) of electronic cigarettes also contains nicotine and its amount is intended for long-term use which can lead to overdose and poisoning by nicotine.

Based on the data of the State Revenue Service that are compared with the data of the previous year, the following trends can be observed:

- Excise tax revenue declined by $21 \%$, in 2009 and by $19 \%$ in 2010;

- Tobacco production decreased by $69 \%$ in 2009 and by $95 \%$ in 2010;

- Cigarette retail sales decreased by $37 \%$ in 2009 and by $23 \%$ in 2010 ;

- The share of cigarettes produced in Latvia was $11 \%$ in 2009 and $1 \%$ in 2010;

- Tobacco import of:

$>$ Cigarettes decreased by $34 \%$ in 2009 and by $37 \%$ in 2010;

$>$ Smoking tobacco increased by $18 \%$ in 2009 and by $65 \%$ in 2010;

- The amount of illegal cigarettes withdrawn from circulation increased by $72 \%$ in 2009 and by $19 \%$ in 2010. 


\section{SHS Web of Conferences}

According to the data of the State Revenue Service (SRS) the total amount of 56, 171, 025 pieces of cigarettes were withdrawn from circulation in 2009 as a result of activities (administrative cases and criminal action) of the Customs Criminal Investigation Board of the SRS. The damage of 5.9 million LVL was averted as a result of activities on combating cigarette smuggling. The amount of cigarettes withdrawn from circulation in 2010 increased to $62,451,820$ pieces, which is by $11 \%$ more than in the previous year.

In Latvia the number of daily smokers gradually decreases thanks to the extensive smoking restrictions though tobacco manufacturers use all the available media, radio and television, newspapers, magazines, advertisements and Internet, to advertise their products. Therefore in order to combat the prevalence of smoking first of all it is necessary to limit cigarette marketing and sales and to carry out monitoring and development of tobacco control measures on the state level.

\section{Discussion}

Health of each person and public health in general is affected by different factors - biological, psychoemotional, social, economic and environmental and by people's life style. Health is the basis for the quality of the human life and welfare of each family and the public in general. The aim of the public health policy is to protect, improve and restore the health of the population of Latvia and to extend lifespan of good quality (http://www.vm.gov.lv/index. php?top=121\&id=798). Healthy society ensures efficient and productive development of the national economy.

Each person, community and the state have to take common responsibility for managing, maintaining and improving public health policies of different branches. The main causes of death among population of Latvia are non-infectious diseases: $53.8 \%$ of causes are related to diseases of the circulatory system, $19.9 \%$ to malignant tumours and $7.2 \%$ to external causes. Death rate from the cardiovascular diseases in Latvia is the highest in the European Union and the average age of premature death is the lowest in the EU. The total oncological morbidity rates in Latvia are not considerably different from the average rate in the EU (except the lung cancer) but the mortality rates are higher than in the EU. The external cause mortality is essential in people at working age and in children. In the external cause death group mortality in women (42.5 cases per 100000 people) considerably differs from mortality in men (157.8 cases per 100000 people). Standardized mortality rate prove that in Latvia $48 \%$ of men die under the age of 65 (women - 28\%) while in the European Union only $29 \%$ of men die under the age of 65 . (http://phoebe.vm.gov.lv/misc_db/web.nsf/bf25ab0f47ba5dd 785256499006b1a4/17cb8c1218bf81cdc2257313001f391a/\$FILE/Tabakas_Uzr_programma. pdf).

Factors connected with lifestyle, such as unhealthy diet, insufficient physical activity and harmful habits (smoking, alcohol consumption), affect the development of non-infectious diseases. The most efficient prevention of cardiovascular diseases is giving up smoking and regular physical activities, healthy diet choices and maintenance of adequate body weight. Only 49\% of inhabitants of Latvia consider that the food they consume daily is generally healthy, while 39\% admit that their daily diet is not healthy. Most of the population of Latvia do not have adequate physical activity.

International conference "European Conference on Tobacco or Health" took place in Amsterdam on 28th to 30th March 2011. More than 300 professionals involved in tobacco control, policy makers, researchers, physicians, public health specialists, health promoters, medical students and media representatives attended the conference. Such large scale conferences have been held for the fifth year in a member state of the European Union. This year Sandra Pērkone, a public health specialist from Latvia representing the "The National Coalition of Latvia on Tobacco and Alcohol Control" took part in the conference. A variety of workshops devoted to such topical issues as socio-economic status and smoking, reduction of smoking prevalence among youth, women and pregnant women, reduction of smoking at places for entertainment and at home, the main aspects for giving up smoking, advertising of tobacco in mass media and films, were held at the conference. 
Int. Conf. SOCIETY. HEALTH. WELFARE; Congr. of Rehabilitation Doctors of Latvia

\section{Conclusions}

1. Availability of tobacco products and influence of tobacco industry have contributed to prevalence of tobacco products among young people. Therefore it is necessary to achieve restriction on supply of tobacco products and broad awareness of risks from the use of tobacco products.

2. Smoking restriction policy in Latvia has slightly reduced the prevalence of smoking though to achieve considerable reduction of prevalence of smoking and passive smoking it is necessary to introduce a comprehensive national programme on restriction of smoking. Systematic and comprehensive education of the public is required to encourage the change of public attitude in favour of a healthy lifestyle.

3. The sales of legal cigarettes have decreased in Latvia starting from 2009. However, the increase in tax rates and prices has contributed to the movement of illegal goods therefore it is necessary to take additional restrictive measures concerning the movement of illegal goods.

\section{References}

[1] Дальке, Р., Дальке, М. (2010) Психология курения. [Psychology of Smoking]. СанктПетербург: “Весь”, 175 с.

[2] LR Saeima. Likums "Par tabakas izstrādājumu realizācijas, reklāmas un smēķēěanas ierobežošanu” ar grozījumiem. [Law "On limited sale, advertising and use of tobacco"]. http://www.likumi.lv/doc.php?id=41774

[3] LR Saeima. PVO Vispārējā konvencija par tabakas uzraudzību. [The Framework Convention on Tobacco Control]. http://www.likumi.lv/doc.php?id=98236.

[4] LR MK (Ministru kabinets). Tabakas uzraudzības valsts programma 2006.- 2010. gadam. [The State Tobacco Monitoring Programme for 2006-2010.]. http://phoebe.vm.gov.lv/misc_db/ web.nsf/bf25ab0f47ba5dd785256499006b15a4/17cb8c1218bf81cdc2257313001f391a/\$FILE/ Tabakas_Uzr_programma.pdf.

[5] LR VM (Veselības ministrija). Sabiedrības veselības pamatnostādnes 2011.-2017. gadam. [The Public health guidelines for the 2011.-2017]. http://www.vm.gov.lv/index.php?top=121\&id=798.

[6] Rīgas domes Labklājības departaments. Aptauja: Latvijā ceturtais lielākais smēķējošo skaits starp ES dalībvalstīm. [Poll: Latvian fourth largest number of smokers among the EU Member States]. http://www.narcomania.lv/pub/index.php?id=211\&gid=53\&lid=513 (sk. 30.04.2011).

[7] VEC (Veselības ekonomikas centrs). Latvijas iedzīvotāju veselību ietekmējošo paradumu pētījums, 2008. [Health Behaviour among Latvian Adult Population, 2008.] http://vec.gov.lv/ docs/new2009/Finbalt_2_dala.pdf (sk.20.10.2010.).

[8] VEC (Veselības ekonomikas centrs). Smēķēšanas un alhokola lietošanas izplatība skolas vecuma bērniem Latvijā 1991.-2006. http://sabves.vec.gov.lv/ZinojumuDokumenti/Z_144/ HBSC_smekesana_alkohols.pdf.

[9] VEC (Veselības ekonomikas centrs). Starptautiskais jauniešu smēķēšanas pētījums 2007.gada aptauja Latvijā. [Global Youth Tobacco Survey]. http://vec.gov.lv/uploads/files/4d00db5acc0b7. pdf.

[10] WHO (World Health Organization). 10 facts on the tobacco epidemic and its control, 2008. http://www.who.int/features/factfiles/tobacco_epidemic/en/index.html. 